\title{
The Preservation of Traditional Knowledge and the Cultural Expression of Craft Rumah Gadang's Walls as the Intellectual Property Of West Sumatera
}

Armilia Riza $^{l}$, and Surya Prahara ${ }^{2}$

${ }^{1}$ STKIP PGRI SUMBAR, English Department, Padang, Indonesia

${ }^{2}$ STKIP PGRI SUMBAR, Sociology Department, Padang, Indonesia

\begin{abstract}
This study discusses the problems of the preservation of Minangkabau craft culture, especially the problem of Intellectual Property Rights in the form of traditional knowledge that is on the craft of Rumah Gadang's walls. The method of this research is qualitative. The informant of this study is determined by using purposive sampling. The chosen informants that are people involved in crafting of Rumah Gadang's walls and the Department of Tourism of West Sumatra Province. This research was conducted at Minangkabau representative area of Luhak Nan Tigo (Agam, Tanah Datar, Lima Puluh Kota). The results of the study shows the extinction of craft of Rumah Gadang's walls was caused by the development factor of modern society's mindset, thus eliminating the value of a local culture of desire to learn old local culture. Moreover, the history and the topic of craft of Rumah Gadang's walls are deleted from Muatan Lokal Subject from the elementary to college level. Besides, the absence of efforts of local governments in trying to preserve the cultural values contained in traditional of craft of Rumah Gadang's walls.
\end{abstract}

Keywords: Preservation, Craft Rumah Gadang's Walls, Intellectual Property

\section{Introduction}

The term of World heritage was initiated by UNESCO (United Nations Educational, Scientific and Cultural Organization). UNESCO held a discussion and the first international convention on the world heritage in 1972. In that convention that its theme was The Convention concerning the Protection of World Cultural and Natural Heritage, on November 16, 1972, UNESCO initiated the protection and recognition of the cultural and natural heritage. UNESCO provides protection for a

\footnotetext{
${ }^{1}$ takuyaeek@gmail.com, armiliariza@stkip-pgri-sumbar.ac.id
} 
world-wide cultural heritage that is so vast and becomes homework for Indonesia. Dealing with that issue, Indonesian Government is aware of the importance of intellectual property value in Indonesian folklore, so that it issued the National Copyright Act 1982 on article 10 which is substituted by article 10 of Law no. 19/2002 on Copyright, and the latest in article 13 of the Copyright Bill of 2010.

Meanwhile, the protection of PTEBT in the National Law is different from what people expect. The people think that the issue of the protection of intellectual property and commercialization of PTEBT are less important than the extinction of PTEBT due to lack of recognition and attention of government ${ }^{2}$. In addition, there is no effort for documenting PTEBT and the custodian. Furthermore, there is culture heritage that is owned collectively and inherited without knowing the first founder.

In its development, at least known several types of intellectual property protection in the form of copyright, brand, geographical indication, industrial product design, patent, integrated circuit layout, and trade secrets (Article 1 Section 2 of the WTO Agreement on Trade-Related Aspects of Intellectual Property Rights, 1996). ${ }^{3}$ The emergence of such diversification of protection has led to some negative implications, especially in the perspective of IPRs that exist outside of such grouping, one of which is the absence of protection of traditional knowledge ${ }^{4}$. This has concretely hurt some traditional societies. Hence, it takes a great commitment in realizing PTEBT.

The focus of this research is the existing PTEBT on Minangkabau culture that is carving art of Rumah Gadang Minangkabau. Based on the description above, PTEBT should receive attention and protection through IPR system embodied in bentu program that will be used by the Government to realize the program PTEBT. The government should provide protection to those who develop their own local wisdom, ceremony, art, culinary, medicine, and folklore, tailored to the ecosystem environment in which they live. ${ }^{5}$ If this program cannot be run, Indonesia will lose intellectual property and wisdom in understandin folklore. According to Darrell Posey, the extinction cultured people affects the world lost thousand years knowledge about life and how to adapt in tropical ecosystems. This valuable

\footnotetext{
${ }^{2}$ Sardjono, Agus, 2005. Upaya Perlindungan HKI yang terkait dengan GRTKF di Tingkat Nasional dan Internasional (Upaya yang Belum Sebanding), Jurnal Media HKI vol.II no.2 December 2005, Ditjen HKI. Page. 3

${ }^{3}$ Siagian, Rizaldi, 2006. Jenis-Jenis Pemanfaatan atas Pengetahuan Tradisional dan Ekspresi Folklor yang perlu dilindungi dan Implikasi Pemanfaatannya, Simposium " Menuju UU Sui Generis Perlindungan terhadap Pemanfaatan Pengetahuan tradisional dan Ekspresi Folklor", Jakarta 13 November 2006. Hal 5

4 Citrawinda, Cita, 2006. Perlindungan terhadap Karya Budaya yang Tidak diketahui Penciptanya, Jurnal Media HKI vol.III no.1 Feb 2006, Ditjen HKIIASTP AUSAID, 2003. Page. 3

${ }^{5}$ According to LSM, Aliansi Masyarakat Adat Nusantara, sampai dengan $2010 \mathrm{di}$ Indonesia terdapat 1163 kelompok masyarakat adat dengan populasi antara 50 sampai 70 juta orang yang menempati 5 juta hektar hutan adat. Read "Membagi Sumber Daya Alam secara Adil”, KOMPAS, 25 Februari 2010.
} 
information is lost immediately. ${ }^{6}$ In addition, the protection of culture will determine the existence and the identity of a nation can be maintained and enhanced and can encourage people to improve the quality of the resulting creation.

The art of carving in Minangkabau is on every side of Rumah Gadang's building. Carving is placed on the whole body of the building. The walls, doors, windows are decorated with carvings consisting of several motifs. Each of the motifs has a deep meaning, Minangkabau traditional carving is divided into three types based on the inspiration of the formation of carvings, the first carvings inspired by the names of plants such as Aka Barayun, Aka Duo Gagang, Aka Taranang, and so forth. Secondly, it is inspired by animal names, such as Ayam Mancotok dalam Kandang, Bada Mudiak, and so forth. The third is inspired carvings of objects used in everyday life such as Ambun Dewi, Aie Bapesong, Ati-ati, Carano Kanso, Jalo Taserak and so forth.

The reason why Rumah Gadang Minangkabau carving is chosen is that the carvings have cultural expression and traditional knowledge values which are known by Minangkabau people only and it is extinct. It is happen because the number of Rumah Gadang that has original motifs of Minangkabau carving is decreased. Another reason is that it is one of the efforts to prevent the stealing of the cultural expression and traditional expression of Rumah Gadang by the foreign parties like 34 cultures that have been stolen ${ }^{7}$ such as Reog Ponorogo dance, Pendet dance, Rasa Sayange Song and Rendang Minang. ${ }^{8}$

This research aims to find the causes of the extinction of traditional knowledge that focuses on Rumah Gadang Minangkabau carving. The novelty of this research to produce a program of Traditional Knowledge Protection, Culture and Cultural Expression Preservation that can be used by the government, especially the West Sumatera local government to protect the folklore art of Rumah Gadang carving. The significance of this research is to create the protection law of PTEBT and folklore, so it cannot be claimed by other countries.

\section{Methods}

There are two different research method used to answer the problem of the real condition of the extinction of the art of wall carvings of Rumah Gadang

\footnotetext{
${ }^{6}$ Posey, D.A., "Indigenous Knowledge and Development: An Ideological Bridge To the Future", dalam Posey, D.A. (K. Plenderleith, ed.), Kayapó Ethnoecology and Culture, Routledge, London and New York, 2002, page. 59, sebagaimana dikutip dalam Dutfield, Graham, Protecting Traditional Knowledge and Folklore, A Review of Progress in Diplomacy and Policy Formulation, International Trade \& Sustainable Development Series, ICTSD - UNCTAD, Switzerland, 2003, page. 25

${ }^{7}$ Maya Sofia dan Tasya Pramitha, Upaya Pemerintah Agar Budaya Indonesia Tak DIklaim Negara Lain, www.life.viva.co.id, retrieved on December 23, 2016.

${ }^{8}$ www.antaranews.com, Warisan Budaya Indonesia Rawan DIklaim Negara Lain, retrieved on December 23, 2016
} 
Minangkabau in West Sumatra and the stakeholders' problems on the barriers to the preservation and protection of traditional knowledge, especially the art of wall carvings Rumah Gadang. Sociological Research methodology with a qualitative approach is used. ${ }^{9}$ To answer the content of IPR protection issues, legal instrument analysis on the protection and preservation of cultural and cultural expression, Law Research methodology with normative legal approach is used.

The methods of collecting the primary data on sociological approach are interviews and observations. Meanwhile, the secondary data is gotten from documents related to this research. Normative legal approach method only relies on the secondary data consisting of primary legal material in the form of international and national law regulation governing folklore and secondary law material in the form of articles and journals related to this research. Informant of this research is conducted by purposive sampling method. The location of the research is in West Sumatera Province, the research area will be represented by the areas that mostly have Rumah Gadang

\section{Result and Discussion}

Based on the findings of the field, traditional art of Rumah Gadang's carving has faded and lost its identity and role. The picture of Rumah Gadang carving is only a symbol without meaning and becomes a dead object that only has artistic value. Minangkabau society does not know much about the aesthetics value, and the meaning of philosophy contained in it. The influence of globalization and the modern mindset due to the disclosure of information and thought has undermined the Minangkabau customs. This condition can be seen from the social development of Minangkabau people who have abandoned the noble values of birth customs. This is manifested by obsolete, Shrubs and the collapse of Rumah Gadang (baganjong) in Minangkabau hinterland, such as Tanah Datar, Solok, Agam, and Lima Puluh Kota, as well as several other areas.

It is very unfortunate circumstances above occurs when the leader of Minangkabaunese mostly background as Penghulu or Datuak as the figure holding of sako jo pusakon lamo. All these circumstances seem to have occurred systematically symbols of Minangkabau customs are swallowed by the period. The results of this study explain that this happens because of several factors:

1. The development of modern societies' mindset, thereby eroding the value of a culture, forcing the absence of a desire to degrade the skills, knowledge of Rumah Gadang Carving to descendants / custodians and the absence of desires from the descendants as custodians of the engraver to continue the skill.

2. The absence of formal education that gives knowledge of local content to learners in particular.

\footnotetext{
${ }^{9}$ Bungin, Burhan, 2010. Analisis Data penelitian Kualitatif. Jakarta: PT Raja Grafindo Persada. Page. 5
} 
3. The existence of a commercial carving industry that produces traditional carvings of Rumah Gadang without knowing the aesthetic value that exists in the traditional carving Rumah Gadang.

4. Less optimal effort of local government in preserving cultural values, especially those contained in the traditional carving art of Rumah Gadang. This is due to the absence of a clear program to address the problem.

5. The absence of legal products at the PERDA level to the PERNA level that focuses on the preservation of regional culture.

From the seven factors that have been described, according to the authors the main cause of the waning beginnings of traditional art of Rumah Gadang is due to the lack of understanding on the aesthetic values and custom meanings contained in the art of carving. The lack of seriousness of governments in preserving the traditional culture of the region is also a factor of extinction of the values and aesthetics that exist in the arts and culture of the region.

In line with the intention and effort to preserve and develop traditional knowledge and culture, it has been agreed upon a charter called Piagam Pelestarian Pustaka Indonesia 2003 which was declared in December 2003 in Ciloto, West Java. The definition of conservation adopted in the charter is the effort of library management through research activities, planning, protection, maintenance, utilization and supervision. The use of the term "protection" has a broad meaning, which means also the effort of preservation and protection of IPR in PTEBT Indonesia. Conservation can also include selective development to maintain continuity, harmony, and carrying capacity in response to the dynamics of the times. (Afrillyanna Purba, 2012: 137).

In the Draft Law on the Protection and Utilization of Intellectual Property of Traditional Knowledge and Traditional Cultural Expression commonly abbreviated as PTEBT explains that Traditional Knowledge and Traditional Culture Protected Expression include cultural elements that are compiled, developed, maintained and transmitted within the tradition and have special characteristics that are integrated with a particular cultural identity of the community that preserves it. Traditional protected cultural expression includes one or a combination of forms one of which is the game. Along with the improvement of technology and cultural transformation towards modern life as well as the influence of globalization, the cultural heritage and traditional values of indigenous peoples face challenges and obstacles to their existence. This needs to be observed because the cultural heritage and traditional values should be preserved, adapted or even developed further.

The question is how the efforts of West Sumatera government in preserving folklore art of wall painting Rumah Gadang as local cultural heritage. Citing the opinion of Koentjaraningrat that the development of Indonesian national culture needs to be oriented to the glorious era of the ancestors of the Indonesian nation that has been past, but also to the present because culture needs to give the ability of the Indonesian nation to face the civilization of today's world. (M.Mandandar Sulaeman, 1998: 43). Efforts of West Sumatera local government in preventing regional culture can be seen through Conservation concepts contained in West Sumatra Provincial Regulation No. 6 of 2014 on Strengthening of Indigenous Institutions and Minangkabau Culture Preservation 
This regulation was made with the idea that the state recognizes and respects the unity of indigenous and tribal peoples as well as their traditional rights as long as they are alive and in accordance with the development of society and the principle of the Unitary State of the Republic of Indonesia. That due to the decrease of custom and cultural values of Minangkabau due to various negative influences, it is necessary to strengthen the customary institution and preserve the Minangkabau cultural values. Besides that in the framework of the implementation of regional autonomy, the Regional Government has the duty and obligation to strive for the preservation of regional culture as well as to ensure legal certainty towards the effort of preserving the cultural values of the region and based on that consideration it is necessary to stipulate the Regional Regulation on Strengthening of Customary Institution and Preserving Minangkabau Culture Value.

When viewed from the legal instrument, this Regulation is the implementing regulation of several laws and regulations, among others, the Minister of Home Affairs Regulation No. 39 of 2007 on Guidelines for Facilitation of Community Organizations in Culture and Customary Institutions in Strengthening and Preservation of Regional Culture, Regulation of the Minister of Home Affairs Number 52 of 2007 on Guidelines for Strengthening and Preservation of Customs and Social Values of Cultural Society and, Joint Regulation of the Minister of Home Affairs and Minister of Culture and Tourism Number 42 Year 2009 and Number 40 Year 2009 on Guidelines for Cultural Preservation.

Based on Article 4 of West Sumatra Provincial Regulation No. 6 of 2014 on the Strengthening of Indigenous Institutions and Minangkabau Cultural Preservation, the government should be obliged to play a role in strengthening the culture, from the concept that researchers wake up, should the government have obligations in terms of:

1. The regional government should:

a. facilitate the strengthening of customary institutions;

b. carry out the preservation of Minangkabau cultural values.

2. Encourage the implementation of strengthening customary institutions including the facilitation, coordination and consultation on strengthening customary institutions.

3. Preserve Minangkabau cultural values including:

a. realizing, growing, developing and raising awareness and responsibility for the rights and obligations of communities in the management of Minangkabau cultural values;

b. developing and implementing policies that can ensure the protection and utilization of Minangkabau cultural values;

c. conducting research and development of Minangkabau cultural values;

d. providing information on Minangkabau cultural values;

e. organizing the promotion of Minangkabau cultural values;

f. preveningt efforts to transfer and shift ownership and control on Minangkabau cultural values;

g. coordinating district / city governments in order to ensure the implementation of Minangkabau cultural preservation; And / or 
h. fostering participation and creativity of the community in preserving the Minangkabau cultural values based on mutual cooperation, independence and justice. The obligation to preserve Minangkabau cultural values as referred to in Article 4 is implemented by the Regional Device Work Unit in charge of culture and tourism.

The strengthening of human resources of adat institutions is carried out by conducting activities to increase pemangku adat's knowledge on the preservation of cultural values of Minangkabau. Meanwhile, strengthening facilities and infrastructure of adat institutions can be implemented by facilitating the provision of facilities and infrastructure supporting the operations of customary institutions in order to preserve the Minangkabau cultural values. Therefore, customary institutions act as partners of local governments in empowering, developing and preserving the customs and cultural values of Minangkabau in the life of society and customary institutions should be involved in:

1. making decisions;

2. formulating decisions relating to the strengthening of customary institutions and the preservation of Minangkabau cultural values; and / or

3. planning and synergizing development programs to conform to Minangkabau cultural values

The development of Minangkabau cultural values is done by:

1. Conducting study and research of Minangkabau cultural values in order to explore the potential of Minangkabau culture;

2. Conducting socialization, seminars, workshops and discussions of Minangkabau cultural values through educational, mass media and other publications.

The development of Minangkabau cultural values as intended is done by maintaining the cultural roots that are owned and not intended to replace existing cultural elements as well as by observing the culture and custom of mutual Nagari.

For the utilization of Minangkabau cultural values is done by:

1. dissemination of information;

2. cultural performances;

3. packaging of teaching materials;

4. packaging of study materials; and

5. developing tourism

Dissemination of information on Minangkabau cultural values is done in the form of:

1. socializing through printed media, electronic media matters relating to the utilization of Minangkabau cultural values, and / or

2. having seminars, discussions, conferences on the theme of Minangkabau culture.

In addition, the dissemination can also be implemented with the performance of Minangkabau cultural values that can be done in the form of:

1. organizing the Minang art festival regularly; And / or

2. displaying the values, norms of customs and traditions of Minangkabau at the exhibition which is followed and organized by the Regional Government. 
The five concepts of efforts undertaken by the West Sumatra Regional Government in preserving the culture of the region hve not been fully implemented. This is certainly caused by several important factors. These factors will be discussed through other sub-chapters in this study.

\section{Conclusion}

The conclusion of this research is the factors causing almost extinction of art of wall carving of Rumah Gadang Minangkabau caused by modern society mindset that is influenced by globalization so that erodes the value of a culture so that force the absence of desire to decrease skill, and knowledge of Rumah Gadang engraving to offspring / custodians and the absence of the desires of the descendants of the tribe as custodians of the engraver to continue the skill. Another factor is the absence of formal education that gives the learners special knowledge about traditional carving art (this should be part of a program that is in the hands of the local government as an effort to preserve local culture). There is no regulation at the level of PERDA to the level of PERNA which is accompanied by the program which is significant to ensure the preservation of regional culture, especially the art of wall carving of Rumah Gadang Minangkabau. Finally, there is no facility to facilitate the engraver (both custodian and not engraver) in the form of an alliance or an association.

A bunch of thank deliver to Directorate General of Research and Technology Research and Development of Ministry of Research, Technology and Higher Education who has appreciated this research by providing funding so that this research can be implemented properly. Moreover, our appreciation goes to all carving artisan, Wali Nagari of Luhak Nan Tigo who have participated as the informant of this research.

\section{References}

Bungin, Burhan. Analisis Data penelitian Kualitatif. Jakarta: PT Raja Grafindo Persada. (2010)

Citrawinda, Citra. Perlindungan terhadap Karya Budaya yang Tidak diketahui Penciptanya, Jurnal Media HKI vol.III no.1 Feb 2006, Ditjen HKIIASTP AUSAID, 2003. (2006)

Posey, D.A. Indigenous Knowledge and Development: An Ideological Bridge To the Future", in Posey, D.A. (K. Plenderleith, ed.), Kayapó Ethnoecology and Culture, Routledge, London and New York, 2002, page. 59, cited by Dutfield, Graham, Protecting Traditional Knowledge and Folklore, A Review of Progress in Diplomacy and Policy Formulation, International Trade \& Sustainable Development Series, ICTSD - UNCTAD, Switzerland, 2003, page. 25 
Sardjono, Agus. Upaya Perlindungan HKI yang terkait dengan GRTKF di Tingkat Nasional dan Internasional (Upaya yang Belum Sebanding), Jurnal Media HKI vol.II no.2 Desember 2005, Ditjen HKI (2005)

Siagian, Rizaldi. Jenis-Jenis Pemanfaatan atas Pengetahuan Tradisional dan Ekspresi Folklor yang perlu dilindungi dan Implikasi Pemanfaatannya, Simposium" Menuju UU Sui Generis Perlindungan terhadap Pemanfaatan Pengetahuan tradisional dan Ekspresi Folklor, Jakarta, 13 November 2006. page 5 (2006)

Sofia, Maya and Paramitha, Tasya. Upaya Pemerintah Agar Budaya Indonesia Tak DIklaim Negara Lain, www.life.viva.co.id, retrieved on December 23, 2016

www.antaranews.com. Warisan Budaya Indonesia Rawan DIklaim Negara Lain, retrieved on December 2, 2016. 